\title{
Appraisal of Revenue Generation in Numan Southwestern Adamawa State, Nigeria
}

\author{
Jamala, G. $\mathrm{Y}^{1^{*}}$, Asongo, A.I $\mathrm{I}^{2}$, Mahai, $\mathrm{S}^{1}$ and Tarfena, H. $\mathrm{J}^{3}$ \\ ${ }^{1}$ College of Agriculture, Ganye, Adamawa State, Nigeria 2 \\ ${ }^{2}$ Modibbo Adama University of Technology, Yola, Nigeria \\ ${ }^{3}$ Ministry of Finance, Yola, Adamawa State, Nigeria
}

\begin{abstract}
This study was conducted to evaluate revenue generation in Numan, Southwestern Adamawa State, Nigeria. One hundred and twenty questionnaires were administered to randomly selected staff of Finance, Education, Administration and Livestock departments respectively. All the questionnaires were completed and returned. Descriptive statistics such as Tables, Frequency distributions, and percentages were used to analyze the data generated. The respondents indicate that sources of internally generated revenue in the study area ranges from Market, Animal sales, land, Slaughter slaps, property and income taxes respectively. Slaughter slap tax account for about $26.7 \%$ of the internally generated revenue in this area, while market sales tax and animal taxes account for about $16.7 \%$ respectively. To improve revenue generation in the study area, the respondents (56.7\%) indicates that they normally employed the use of law enforcement agents to assist in revenue generation and this had yield some measures of improvement in the amount of revenue generated from 2005 to 2009. Although, there has been an increased in the amount of targeted internally generated revenue from 2005 to 2009 , the respondents indicated that majority of the taxpayers do not comply in prompt payment of taxes $(40 \%)$. Some of the factors responsible for inefficiency of revenue generation in the study area as indicated by the respondents includes inadequate public enlightenment (33.3\%), while others (23.3\%) are in the opinion that inadequate incentives is also a contributory factor. Based on the findings of this study, the following recommendations were made: Regular training of the revenue officers should be introduce and maintain, regular public enlightenment on the benefits of tax payment should be introduce either through the media or workshop and also through the use of posters, and the incentives given to revenue officers should be enhance and the best revenue officers of the year should be rewarded.
\end{abstract}

Keywords: Revenue, Tax Evasion, Appraisal, Expenditure, Government

\section{Introduction}

Revenue, receipts of a government or a business. Governments raise revenue mainly through taxation, in order to pay for government expenditure on capital and recurrent expenditures. Revenue generation provide the largest single source of government revenues in most developed and developing countries, including Nigeria. The revenues generated pay for a substantial part of government operations and services to the public. In Nigeria, the Federal, States, and the Local governments generate internal revenues. State and Local governments generate larger shares of their revenues from property taxes and sales taxes than from income taxes. Income taxes, and especially individual income taxes, are smaller sources of revenue in most developing countries, such as many nations of Africa, Asia, and Latin America. Some developing countries, however, generate a large portion of government revenues from corporate income taxes. Governments levy income taxes on many kinds of earnings, including wages and salaries from work, rents (fees for use of property), interest on savings, shareholder dividends from investments in businesses, capital gains (profits made from the sale of financial assets), government compensation programs, educational grants and scholarships, and legal settlements. The local government system relied heavily on two sources for its revenues: statutory allocation and locally generated revenues (taxes on specific items, such as alcohol, slaughter slap, land, shops/kiosks etc), and property taxes.

\section{History of Revenue Generation}

According to Rosen et al. (2009), early systems of public finance often taxed a variety of goods and activities, including property, trade, and sometimes wealth. Administrators in England attempted to collect the first true income tax, a tax on wages, in 1404, but the public quickly demanded its repeal, and all tax records were burned.

Modern forms of tax collection date to a British income tax levied in 1799, this tax raised revenues for the Napoleonic Wars against France, which Britain and a coalition of other European nations won in 1815. By popular demand, the British repealed a second income tax in 1816. All of these tax records were also burned. In 1842 Britain introduced another income tax that was less burdensome. This tax survived, and within a few 
decades, income taxes provided significant revenues to the British government. By the end of the 19th century, Germany, the Netherlands, Sweden, Switzerland, Canada, and several other countries had enacted income taxes. The development of income tax in Nigeria has been great influenced by the provision of the 1954 constitution, which related to the sharing of income tax among tiers of government. Three tiers of government namely, the Federal, the State and the Local Government are charged with tax administration in Nigeria, (Alabede, 2001).

\section{Public Revenue}

Government must have funds, or revenue, to pay for their activities. Governments generate some revenue by charging fees for the services they provide. Most government revenue comes from taxes, such as income tax, capital taxes, and sales and excise taxes. An important source of tax revenue in most industrialized countries is the income or payroll tax, also known as the personal income tax. Income taxes are imposed on labor or activities that generate income, such as wages or salaries. The federal government, many state governments, and some local governments levy personal income taxes. Another important source of government revenue is the capital tax. Capital includes items or facilities that generate profits, such as factories, business machinery, and real estate. Some types of capital taxes are known as "profits" taxes. A property tax is a capital tax used by state and local governments. Property taxes are levied on items such as houses or boats.

Sales and excise taxes are also a major source of government tax revenue. Many state and local governments levy a sales tax on the purchase of certain items. Consumers usually pay a percentage of the sales price as the tax. Excise taxes are used by all levels of government. An excise tax is levied on a specific product, such as alcohol, or gasoline. The tax is usually included in the purchase price (Robert, 2009).

\section{Collection and Filing of Revenues}

In the United States, the Internal Revenue Service relies on taxpayers to comply with the law and voluntarily calculate and pay their taxes. The agency also monitors tax evasion, instances in which people or corporations illegally avoid paying some or all of their required income taxes. The IRS may audit (check for accuracy and compliance in payment) anyone they suspect of tax evasion by requesting complete records of all earnings and expenses, (Rosen et al., 2009).

In Nigeria, Ola (2004), states that taxpayer is issued with the Income Tax Return Form for his or her completion. It is a return of income claims for allowances and relieves. The law requires that the annual return of income (forms) should reach the taxpayer between $1^{\text {st }}$ January and $28^{\text {th }}$ February, otherwise the taxpayer should demand one.

\section{Objectives of Revenue Generation}

According to Okezie (2003), the primary purpose of revenue generation is to raise income for government expenditure. It is the best and quickest mode of raising revenue open to government for economic activities in order to increase the quality of life of its citizens.

\section{Problems of Revenue Collection}

Loopholes and Shelters: Tax loopholes develop when tax laws create ways for taxpayers to legally avoid paying taxes on some earnings. Tax shelters shield certain kinds of income from some or all taxation. People can move income from a place that is subject to standard taxation, such as a personal savings account, into a sheltered place, such as a low-tax or tax-free investment. A very simple type of shelter involves transferring capital income (dividends and interest) from someone who has a high marginal tax rate to someone who has a low marginal tax rate, (Rosen et al., 2009)

Akpan (1993), identified embezzlement and diversion of funds as a problem of tax collection, that result in the lost of huge sum of revenue to fraudulent staff charged with the responsibility of tax collection. Ubeku (1976), reports that, non performance of employee due to poor motivation and lack of training as a major threat to effective tax collection. Hence tax collectors should be adequately motivated in order enhance effective tax collection. Tabanshi, (1997) pointed out that another problem of tax collection is the failure by tax payers to submit their correct information for assessment. While Zorto (1996), enumerates inadequate legal policies, poor system of accountability of the tax officials and lack of adequate awareness/campaign on the importance of tax, as some of the constraints of tax collection and filing. Adedeji (1970) blames the ineffectiveness of local administration on lack of mission or comprehensive functional role, lack of proper structure to enhance the development revenue base, lack of qualified and experienced tax officials to handle tax assessment and collection. 


\section{Types and Forms of revenue collected by Local Government}

Taxes and levies to be collected by the local government include: Shops and Kiosks rates, Tenement rates, On and Off liquor license taxes, Slaughter slap taxes, Marriage, birth and death registration taxes, Naming of street registration taxes, Right of Occupancy taxes on land in rural areas and Market taxes, (Alabede, 2001). One of the major challenges of revenue generation in Nigeria is that of compliance of the tax payers and the administration of tax. Most often there is shortage of well trained and qualified personnel which suppose to serve as tool for revenue generation at the local government level, even the few available are not properly trained and efficient in budgetary and financial management systems. At the same time the incentives given to the revenue collectors is often low and at the end of the taxpaying process, poorly paid revenue collectors are all too easily tempted by bribes and the whole process corrupted. The objective of this study was to evaluate revenue generation in Numan Southwestern Adamawa State, Nigeria.

\section{Materials and Methods}

The Study Area: The Study was carried out in Numan, Numan Local Government Area of Adamawa State (longitude $10^{\circ} 24^{\prime}$ and $12^{\circ} 55^{\prime} \mathrm{E}$ and latitude $9^{\circ} 10^{\prime}$ and $9^{\circ} 39^{\prime} \mathrm{N}$ and covers a land area of about $2,193 \mathrm{~km} .^{2}$ The climate of Numan is that of the guinea savannah region ranging from $28^{\circ} \mathrm{C}$ to $32^{\circ} \mathrm{C}$ with a mean rainfall of 676 $\mathrm{mm}$ (Girei and Giroh, 2012)

Data collection: Questionnaires were administered to 120 respondents which was the main source of data collection for the research work and this was complemented by oral interview amongst other sources.

\section{Design of the Study}

This study employs the use of survey research method, due to the nature of the research, which involves practical issues. The questionnaire was designed to find out views concerning appraisal of revenue generation, with special reference to Numan Local government area of Adamawa State.

The target population comprises of some randomly selected departments of Numan local government involved in revenue generation (Finance, Livestock, Education and Administration, respectively). From the population of the study, one hundred and twenty (120) respondents, were randomly selected and served with questionnaires respectively.

\section{Method of Data Analysis}

The main tools for data analysis were descriptive statistics such as table, frequency distribution, and percentages for analyzing the data collected and used for drawing inference on the population.

\section{Results and Discussion}

One hundred and twenty questionnaires were administered to randomly selected staff of Finance, Education, Administration and Livestock departments respectively in the study area. Information regarding the particulars of the sampled staff, which include sex, marital status, age, qualification, working experience, personnel responsible for revenue generation, various forms of revenues generated in the study area, approaches employed for revenue generation, factors responsible for inefficiency of revenue generation in the study area and intervention policies that will enhance adequate revenue generation were analyzed and presented in Table 1 to 4 .

The findings of this study reveal that, all the sampled respondents are revenue officers from the departments of Finance, Livestock, Education and Administration respectively. Majority of the respondents are between the ages of 41 to 50 years, and mostly females (53.3\%). Highest percentages $(76.7 \%)$ of the respondents either male or female are married. Based on the highest qualification attainment of the respondents, majority are Diploma/NCE holders $(66.7 \%)$ and $16.7 \%$ were holders of HND/Degree and post graduate certificates. This indicates that most of the revenue officers in the study area had average qualification in revenue generation and filing processes, and this was contrary to the observation of Adedeji (1970), who blames the ineffectiveness of local administration on lack of mission or comprehensive functional role, lack of proper structure to enhance the development revenue base, lack of qualified and experienced tax officials to handle tax assessment and generation.

About $33.3 \%$ of the respondents had 6 to 10 years working experience and $26.7 \%$ had 11 to 15 years, while $23.3 \%$ has 16 and above years of working experience. The sources of internally generated revenue in the study area ranges from market, animal, sales, land, slaughter slaps, property and income taxes respectively. Slaughter slap tax account for about $26.7 \%$ of the internally generated revenue in this area, while market sales tax and animal taxes account for about $16.7 \%$ respectively (Table 1 ). These sources of internally generated revenues agreed with the report of (Alabede, 2001). 
Table 2 reveals that all the respondents $(100 \%)$ are revenue officer in the study area. The various sources of internally generated revenue in the study area as indicated by the respondents, includes; slaughter slap tax provide the highest internally generated revenue (26.7\%), followed by animal sales tax and market sales tax respectively (Table 2). The targeted internally generated revenue from 2005 to 2009 revealed that there was a progressive increased in the generated revenue from 2005 to 2009.

In order to improve revenue generation in the study area, the respondents $(56.7 \%)$ indicates that they normally employed the use of law enforcement agents to assist in revenue generation and this had yield some measures of improvement in the amount of revenue generated from 2005 to 2009. Although, there has been an increased in the amount of targeted internally generated revenue from 2005 to 2009, the respondents indicates that majority of the taxpayers do not comply in prompt payment of taxes in the study area due to tax evasion and avoidance which accounts for almost $40 \%$, the respondents indicated, this agrees with the observation of (Zorto, 1996). With respects to the type of approach employed for revenue generation, the respondents $(46.7 \%)$ indicate that the direct approach was mostly adopted in the study area (Table 3). While, $33.3 \%$ of the respondents indicate that sometimes, the task force on revenue generation approach was used simultaneously. Some of the factors responsible for inefficiency of revenue generation in the study area as indicated by the respondents includes inadequate public enlightenment account for about $33.3 \%$, while others $(23.3 \%)$ are in the opinion that inadequate incentives is also a contributory factor. Tax evasion and avoidance some of the respondents $(20 \%)$ maintained that is also a factor. Nevertheless, the best intervention policies for effective revenue generation according to the respondents include; regular public enlightenment on the benefits of tax payment, use of extra-legal means to generate revenue and regular training of revenue officers respectively (Table 4)

\section{Conclusions}

The findings of this study reveals that, although revenue generation is an important tool for making local revenue available for government use, at present there are series of challenges to cope with in order to improve internally generated revenue in the study area. These challenges include regular public enlightenment on the benefits of tax payment, regular training of revenue officers and supervision and the improvement of revenue officers incentives which will serve as motivation for greater performance.

\section{Recommendations}

Based on the findings of this study, the following recommendations are made in order to improve the revenue generation base of the study area and hence increase in the amount of revenue locally generated.

- Regular public enlightenment on the benefits of tax payment should be introduced either through the media or workshop or through the use of posters.

- Regular training of the revenue officers should be introduce and maintain

- The incentives given to revenue officers should be enhance and the best revenue officer of the year should be rewarded if possible.

- More qualified revenue personnel should be employed in order to enhance revenue generation in the study area.

- Regular monitoring and supervision of revenue officers should be enhance.

Table 1: Socio-characteristics distribution of respondents

\begin{tabular}{|l|l|l|}
\hline Age (Years) & Frequency N=120 & Percentage (\%) \\
\hline $20-30$ & 12 & 10 \\
\hline $31-40$ & 48 & 40 \\
\hline $41-50$ & 52 & 43.3 \\
\hline $51-60$ & 8 & 6.7 \\
\hline Total & $\mathbf{1 2 0}$ & $\mathbf{1 0 0}$ \\
\hline Sex & \multicolumn{2}{|l|}{} \\
\hline Male & 56 & 46.7 \\
\hline Female & 64 & 53.3 \\
\hline Total & $\mathbf{1 2 0}$ & $\mathbf{1 0 0}$ \\
\hline Marital Status & \multicolumn{2}{|l|}{} \\
\hline & \multicolumn{2}{|l|}{} \\
\hline Married & 92 & 76.7 \\
\hline Unmarried & 28 & 23.3 \\
\hline Total & $\mathbf{1 2 0}$ & $\mathbf{1 0 0}$ \\
\hline Qualification & \multicolumn{2}{|l|}{} \\
\hline Diploma/NCE & 80 & 66.7 \\
\hline HND/Degree & 20 & 16.7 \\
\hline Post graduate & 20 & 16.7 \\
\hline Total & $\mathbf{1 2 0}$ & $\mathbf{1 0 0}$ \\
\hline
\end{tabular}




\begin{tabular}{|l|l|l|}
\hline Working experience (Years) & 20 & 16.7 \\
\hline $1-5$ & 40 & 33.3 \\
\hline $6-10$ & 32 & 26.7 \\
\hline $11-15$ & 28 & 23.3 \\
\hline 16 and above & $\mathbf{1 2 0}$ & $\mathbf{1 0 0}$ \\
\hline Total & 48 & 40 \\
\hline Distribution of respondents based on Department & 20 \\
\hline Finance & 24 & 10 \\
\hline Livestock & 12 & 30 \\
\hline Education & 36 & $\mathbf{1 0 0}$ \\
\hline Administration & $\mathbf{1 2 0}$ & \\
\hline Total & & \\
\hline
\end{tabular}

Source: Field Survey (2010)

Table 2: Are you a revenue officer?

\begin{tabular}{|c|c|c|}
\hline Response & Frequency $\quad \mathrm{N}=120$ & Percentage $(\%)$ \\
\hline Yes & 120 & 100 \\
\hline No & - & - \\
\hline Total & 120 & 100 \\
\hline \multicolumn{3}{|c|}{ Sources of internally generated revenue } \\
\hline Sales tax & 8 & 6.7 \\
\hline Income tax & 8 & 6.7 \\
\hline Market tax & 20 & 16.7 \\
\hline Land Tax & 12 & 10 \\
\hline Animal tax & 20 & 16.7 \\
\hline Company tax & 4 & 3.3 \\
\hline Property tax & 4 & 3.3 \\
\hline Slaughter slap tax & 32 & 26.7 \\
\hline Individual income tax & 8 & 6.7 \\
\hline Value-added tax & 4 & 3.3 \\
\hline Total & 120 & 100 \\
\hline \multicolumn{3}{|c|}{ Targeted revenue for these previous years $(2009-2005)$} \\
\hline Year & Targeted Revenue (N) & \\
\hline 2009 & $51,819.146: 00$ & \\
\hline 2008 & $46,719.849: 00$ & \\
\hline 2007 & $40,897.653: 00$ & \\
\hline 2006 & $35,795.775: 00$ & \\
\hline 2005 & $45,399.899: 00$ & \\
\hline \multicolumn{3}{|c|}{ Generated as revenue in these previous years $(2009-2005)$} \\
\hline Year & Targeted Revenue $(\mathrm{N})$ & \\
\hline 2009 & $40,732.190: 00$ & \\
\hline 2008 & $39,819.779: 00$ & \\
\hline 2007 & $34,871.317: 00$ & \\
\hline 2006 & $30,018.141: 00$ & \\
\hline 2005 & $24,137.445: 00$ & \\
\hline
\end{tabular}

Source: Field Survey (2010)

Table 3: Do the tax payers usually comply in prompt payment of the tax?

\begin{tabular}{|l|l|l|}
\hline Response & Frequency N=120 & Percentage (\%) \\
\hline Yes & 52 & 43.3 \\
\hline No & 68 & 56.7 \\
\hline Total & $\mathbf{1 2 0}$ & $\mathbf{1 0 0}$ \\
\hline Reasons for none compliance & Respondents & Percentage (\%) \\
\hline Reasons for non compliance in tax payment & 48 & 40 \\
\hline Tax Evasion and Avoidance & 28 & 23.3 \\
\hline Improper use of taxes & 20 & 16.7 \\
\hline Ignorance & 24 & 20 \\
\hline Inadequate information about tax requirement & 120 & 100 \\
\hline Total & $\mathbf{F r e q u e n c y} \mathbf{N = 1 2 0}$ & Percentage (\%) \\
\hline Methods Use to Improve Revenue Generation & 68 & 56.7 \\
\hline Use of law enforcement agents & 52 & 43.3 \\
\hline Yes & $\mathbf{1 2 0}$ & $\mathbf{1 0 0}$ \\
\hline No & \multicolumn{2}{|l|}{} \\
\hline Total & Respondents & Percentage (\%) \\
\hline improvement in revenue generation & 68 & 56.7 \\
\hline Response & 52 & 43.3 \\
\hline Yes & $\mathbf{1 2 0}$ & $\mathbf{1 0 0}$ \\
\hline No &
\end{tabular}




\begin{tabular}{|l|l|l|}
\hline Approach do you use in revenue generation & Respondents & Percentage (\%) \\
\hline Type of Approach & 56 & 46.7 \\
\hline Direct Approach & 8 & 6.7 \\
\hline Indirect Approach & 40 & 33.3 \\
\hline Task force Approach & 16 & 13.3 \\
\hline Both Approaches & $\mathbf{1 2 0}$ & $\mathbf{1 0 0}$ \\
\hline Total &
\end{tabular}

Source: Field Survey (2010)

Table 4: What are the factors responsible for inefficiency of revenue generation?

\begin{tabular}{|l|l|l|}
\hline Factors Responsible for inefficiency & Frequency N=120 & Percentage (\%) \\
\hline Lack of qualified and experienced revenue officers & 12 & 10 \\
\hline Tax Evasion and Avoidance & 24 & 20 \\
\hline Inadequate manpower & 16 & 13.3 \\
\hline Inadequate incentives & 28 & 23.3 \\
\hline Inadequate public enlightenment & 40 & 33.3 \\
\hline Total & $\mathbf{1 2 0}$ & $\mathbf{1 0 0}$ \\
\hline Best intervention policy(s) for effective revenue generation & \multicolumn{2}{|l|}{ Frequency N=120 } \\
\hline Best intervention policies & 4 & Percentage (\%) \\
\hline Increase incentives for revenue officers & 68 \\
\hline Regular public enlightenment on the benefit of tax payment & 20 \\
\hline Regular training of revenue officers & 28 \\
\hline Use of Extra-Legal means to generate revenue & $\mathbf{1 2 0}$ & 16.7 \\
\hline Total & \multicolumn{2}{|l}{} \\
\hline Source: Field Survey (2010) & $\mathbf{1 0 0}$ \\
\hline
\end{tabular}

Source: Field Survey (2010)

\section{References}

[1]. Adedeji, A. (1970). Local Government Finance in Nigeria: Problems and prospects, University Press, Ile-Ife

[2]. Akpan, E.H. (1994). Fiscal Federalism: Nigeria Post-Independence Experience 1960-1990, World Development Vol.22, No.8

[3]. Alabede, J.O. (2001). Introduction to Nigerian Taxation, Debis-Co. Publishing Company Ltd. Kano

[4]. Crowther, S. (2007). The Performer Watch, ABTI Printing Press Ltd, Yola,

[5]. Girei, A.A and D.Y. Giroh (2012). Profitability Analysis of Sugarcane (Saccharum officinarum) Production in Numan local government area Adamawa State, Nigeria Jorind 10 (3),141-145www.transcampus.org./journals, www.ajol.info/journals/jorind

[6]. Okezie, S.A. (2003) Personal Income Tax in Nigeria ASO Div. Aba, Nig.

[7]. Ola, C.S. (2004). Income Tax law and Practice in Nigeria, Heinemann Education Books (Nigeria) PLC, Ibadan

[8]. Rosen, Harvey s. "income tax." Microsoft ${ }^{\circledR}$ Encarta ${ }^{\circledR} 2009$ [DVD]

[9]. Tabansi, O.A.C (1997). Nigerian Taxation for Students, Ochiogu Publishers Ltd. Enugu

\section{Acknowledgements}

The authors would like appreciate all staff of Finance, Education, Administration and Livestock departments for their responses and data provided for this study. Thanks also to Numan local government authority, Adamawa State, Nigeria. 